\title{
Heavy metal dynamics in the soil-leaf-fruit system under intensive apple cultivation
}

\author{
Senad Murtić \\ University of Sarajevo, Faculty of Agriculture and Food Science, Sarajevo, \\ Bosnia and Hercegovina
}

Duško Brković, Milena Đurić, Ivan Vujinović

University of Kragujevac, Faculty of Agriculture, Čačak, Serbia

\begin{abstract}
One of the major problems confronting agricultural production is heavy metal contamination of agricultural soils, which imposes considerable limitations on productivity and leads to great consumer health and safety concerns about the products obtained on these soils. The objective of this study was to evaluate heavy metal dynamics in the soil-leaf-fruit system in an intensive apple cv. 'Idared' planting located in the Municipality of Goražde. Heavy metal contents in the soil samples and plant material were determined by atomic absorption spectrophotometry using a Shimadzu 7000 AA device, according to the instructions specified in the ISO 11047 method. The dynamics of the heavy metals analysed, excepting zinc, in the soil-leaf-fruit system was characterised by relatively high total levels of heavy metals in the soil and a very low degree of their accumulation in the leaves and in particular the fruits. No fruit sample was found to have toxic levels of any of the heavy metals analysed. In terms of soil contamination, this suggests the suitability of the study location for safe apple fruit production.
\end{abstract}

Key words: soil, leaf, fruit, heavy metals 


\section{Introduction}

Agricultural lands are the primary resource for food production. Therefore, developed countries invest great efforts to ensure their protection. Actions oriented towards this goal require the use of appropriate measures to maintain long-term soil fertility, while preventing or at least reducing soil contamination with harmful substances.

Among the harmful substances occurring in soils, heavy metals such as cadmium $(\mathrm{Cd})$, chromium $(\mathrm{Cr})$, lead $(\mathrm{Pb})$, mercury $(\mathrm{Hg})$ and arsenic (As) stand out in terms of their potential negative effect on human health, even if found in very small amounts in foods and drinks(Ali et al., 2004: He et al., 2005; Pan et al., 2010). Lead is primarily the causative agent of disorders of the central and peripheral nervous systems in humans; cadmium causes damage to kidneys and bone structure, while chromium, arsenic and mercury have carcinogenic effects (Jašić, 2013). Other heavy metals can also lead to adverse effects on human body functions if their levels in the food ingested are above limit values, but it is noteworthy that some of them, such as zinc, copper and iron, are essential nutrients for both human and plant life (Intawongse et al., 2006).

Heavy metals enter agricultural soils from a variety of sources. They are derived largely from the geological parent material on which the soil has developed and partly from inputs from anthropogenic factors (Alloway, 1995). The most important anthropogenic sources of soil contamination with heavy metals are: harmful emissions from motor vehicles and industrial plants, municipal waste and intensified use of artificial fertilisers and plant protection agents containing heavy metals.

To ensure soil quality and prevent the accumulation of toxic heavy metals in plants, it is essential to understand the dynamics of heavy metals in the soil-leaffruit system, since their presence in soils does not necessarily imply their adverse effects if they do not occur in a form that is easily absorbed by plants. Moreover, when assessing the usability of a soil for agricultural production with respect to heavy metal contamination, it is vitally important that careful consideration be given to the chemical properties of the soil and their effect on the uptake, transport and accumulation of heavy metals in the plant.

It is essential to investigate heavy metal dynamics in the soil-leaf-fruit system in fruit crops as these provide staple food for human diet. Given the above, the objective of the present study was to evaluate the dynamics of heavy metals $\mathrm{Cd}, \mathrm{Cr}, \mathrm{Pb}, \mathrm{Zn}, \mathrm{Cu}$ and $\mathrm{Ni}$ in an intensive apple (Malus domestica Borkh., cv. Idared) planting located in the Municipality of Goražde, and give an insight into the potential for safe fruit production on the study location. The research was conducted on apple cultivar 'Idared'. The reason behind this choice of cultivar is that 'Idared' is commonly grown in apple plantations across Bosnia 
and Herzegovina and Serbia and, therefore, any endeavour to improve its production is of great interest to both the producer and the end consumer.

\section{Materials and methods}

The experiment investigating the dynamics of the heavy metals $\mathrm{Cd}, \mathrm{Cr}, \mathrm{Pb}$, $\mathrm{Zn}, \mathrm{Cu}$ and $\mathrm{Ni}$ in the soil-leaf-fruit system was conducted in 2013 in an intensive apple (Malus domestica Borkh., cv. Idared) planting located in the Municipality of Goražde. To reduce the effect of other agroenvironmental factors on the issue analysed, the experiment included a row of fruit trees with 20 trees of the same age (8 years), grafted on the same rootstock $\left(\mathrm{M}_{9}\right)$ and trained to the same system (slender spindle).

The first part of the experiment involved chemical analysis of an average soil sample collected separately for the topsoil $(0-30 \mathrm{~cm})$ and the subsurface layer (30-60 cm). The average soil sample for each depth analysed was a mixture of several individual samples taken from a number of places on the plot using a graduated soil probe. The chemical analysis involved the following parameters: soil $\mathrm{pH}$, humus content, readily available phosphorus and potassium, and most notably the contents of total and available forms of heavy metals: $\mathrm{Cd}, \mathrm{Cr}, \mathrm{Pb}, \mathrm{Zn}$, $\mathrm{Cu}$ and $\mathrm{Ni}$ in the soil. The following methods of determination were used: a $\mathrm{pH}$ metre (ISO, 1994) for soil $\mathrm{pH}$, the dichromatic method (ISO, 1998) for humus content, AL method for readily available potassium and phosphorus (Egner et.al., 1960.), and atomic absorption spectrophotometry for total and available forms of the heavy metals using a Shimadzu 7000 AA, according to the instructions specified in the ISO 11047 method (ISO, 1998). Total forms of heavy metals were extracted from the soil by aqua regia as extraction agent (ISO, 1995), and available forms of heavy metals by EDTA solution - a mixture of 1 $\mathrm{M}\left(\mathrm{NH}_{4}\right)_{2} \mathrm{CO}_{3}$ and 0.01 ethylenediaminetetraacetic acid (Trierweler et.al., 1969). The second part of the experiment dealt with leaf and fruit sampling from the experimental trees. Leaf sampling was conducted in mid growing season from the middle part of the shoots, an only completely developed, physiologically active and intact leaves were sampled. Fruit sampling was performed at harvest maturity, including five fruits from the middle part of the crown per fruit tree.

The contents of heavy metals in the plant material were determined by atomic absorption spectrophotometry after their extraction from dried leaves and fruits with nitrate and sulphate acids (Lisjak et. al., 2009).

Results on $\mathrm{Cd}, \mathrm{Cr}, \mathrm{Pb}, \mathrm{Zn}, \mathrm{Cu}$ and $\mathrm{Ni}$ contents in the soil and plant material were compared with the limit values set down by related legal regulations in Bosnia and Herzegovina and Serbia, viz. Rulebook on Determination of Allowable Quantities of Harmful and Hazardous Substances in Soils and Methods for Their Testing and Rulebook on Allowable Quantities of Hazardous and Harmful Substances in Soils and Irrigation Waters and Methods for Their 
Testing [15], respectively. For better insight into the degree of heavy metal contamination of the soil and apple leaves and fruit, additional literature sources were used for data analysis: recommendations of the World Health Organisation on maximum allowable concentrations of heavy metals in fruits and vegetables (FAO/WHO Expert Committee on Food Additives, 1999). and scientific literature (Kastori et al., 2003; Kastori et al., 1997). The analysis of data provided a more detailed understanding of heavy metal accumulation in apple fruits depending on the content of these elements in the soil and soil chemical characteristics. Furthermore, conclusions were drawn as to the potential for safe fruit production.

\section{Results and Discussion}

Results on the chemical analysis of the soil on the experimental location are presented in Table 1.

Table 1 - Results on soil chemical analysis

\begin{tabular}{|c|c|c|c|c|}
\hline \multicolumn{5}{|c|}{ Topsoil $0-30 \mathrm{~cm}$} \\
\hline $\begin{array}{l}\text { parameter } \\
\text { tested }\end{array}$ & $\begin{array}{c}\text { unit of } \\
\text { measurement }\end{array}$ & $\begin{array}{c}\text { values } \\
\text { measured }\end{array}$ & method & $\begin{array}{c}\text { soil } \\
\text { characteristics }\end{array}$ \\
\hline $\mathrm{pH}\left(\mathrm{H}_{2} \mathrm{O}\right)$ & - & 7.06 & ISO 10390 & \\
\hline $\mathrm{pH}(\mathrm{KCl})$ & - & 6.40 & ISO 10390 & slightly acid \\
\hline humus & $\%$ & 2.20 & dichromatic $\mathrm{m}$. & moderate supply \\
\hline $\begin{array}{l}\text { phosphorus } \\
\left(\mathrm{P}_{2} \mathrm{O}_{5}\right)\end{array}$ & $\operatorname{mg} 100 \mathrm{~g}^{-1}$ & 3.37 & Al method & very low supply \\
\hline $\begin{array}{l}\text { potassium } \\
\left(\mathrm{K}_{2} \mathrm{O}\right)\end{array}$ & $\mathrm{mg} 100 \mathrm{~g}^{-1}$ & 25.78 & Al method & rich supply \\
\hline \multicolumn{5}{|c|}{ Subsurface layer $30-60 \mathrm{~cm}$} \\
\hline $\begin{array}{l}\text { parameter } \\
\text { tested }\end{array}$ & $\begin{array}{c}\text { unit of } \\
\text { measurement }\end{array}$ & $\begin{array}{c}\text { values } \\
\text { measured }\end{array}$ & method & $\begin{array}{c}\text { soil } \\
\text { characteristics } \\
\end{array}$ \\
\hline $\mathrm{pH}\left(\mathrm{H}_{2} \mathrm{O}\right)$ & - & 6.96 & ISO 10390 & \multirow{2}{*}{ slightly acid } \\
\hline $\mathrm{pH}(\mathrm{KCl})$ & - & 6.36 & ISO 10390 & \\
\hline humus & $\%$ & 1.07 & $\begin{array}{c}\text { dichromatic } \\
\text { method }\end{array}$ & low supply \\
\hline $\begin{array}{l}\text { phosphorus } \\
\left(\mathrm{P}_{2} \mathrm{O}_{5}\right)\end{array}$ & $\operatorname{mg} 100 \mathrm{~g}^{-1}$ & 3.22 & Al method & very low supply \\
\hline $\begin{array}{l}\text { potassium } \\
\left(\mathrm{K}_{2} \mathrm{O}\right)\end{array}$ & $\operatorname{mg} 100 \mathrm{~g}^{-1}$ & 17.14 & Al method & medium supply \\
\hline
\end{tabular}

The soil analysis showed that both soil layers are slightly acid, with a low content of available phosphorus and a medium to high content of available 
potassium. The humus content was medium in the topsoil and quite lower, as expected, in the subsurface layer.

The levels of total and available forms of the heavy metals in the soil and their content in the leaves and fruits of apple cv. 'Idared' are shown in Table 2.

Table 2 - Heavy metal contents in the soil samples and plant material

\begin{tabular}{|c|c|c|c|c|c|c|c|c|c|}
\hline \multirow{2}{*}{$\begin{array}{l}\text { Heavy metals } \\
\left(\mathrm{mg} \mathrm{kg}^{-1}\right)\end{array}$} & \multicolumn{2}{|c|}{$\begin{array}{l}\text { soil } \\
\text { total forms }\end{array}$} & \multicolumn{2}{|c|}{$\begin{array}{l}\text { Limit } \\
\text { values }\end{array}$} & \multicolumn{2}{|c|}{$\begin{array}{c}\text { soil } \\
\text { available } \\
\text { forms }\end{array}$} & \multirow[t]{2}{*}{ leaf } & \multirow[t]{2}{*}{ fruit } & \multirow{2}{*}{$\begin{array}{l}\text { Limit } \\
\text { values } \\
\text { (fruit) }\end{array}$} \\
\hline & $(0-30)$ & $(30-60)$ & $\mathrm{B}-\mathrm{H}^{1}$ & Serbia $^{2}$ & $(0-30)$ & $(30-60)$ & & & \\
\hline chromium & 37.47 & 50.48 & 80 & 100 & 0.44 & 0.49 & 1.17 & 0.24 & $1^{3}$ \\
\hline lead & 56.98 & 37.98 & 80 & 100 & 0.52 & 0.27 & 0.23 & n.d.* & $0.3^{3}$ \\
\hline cadmium & n.d.* & n.d.* & 1 & 3 & n.d.* & n.d.* & n.d.* & n.d.* & $0.2^{3}$ \\
\hline zinc & 217.63 & 230.47 & 150 & 300 & 4.70 & 1.33 & 82.19 & 34.17 & $150^{4}$ \\
\hline copper & 79.70 & 72.36 & 65 & 100 & 9.2 & 4.1 & 15.33 & 0.44 & $15^{4}$ \\
\hline nickel & 36.15 & 35.21 & 40 & 50 & 0.55 & 0.63 & n.d.* & n.d.* & $30^{4}$ \\
\hline
\end{tabular}

* - not detected

limits for concentrations of heavy metals in soils, as prescribed by the B-H legal regulations

${ }^{2}$ limits for concentrations of heavy metals in soils, as prescribed by Serbian legal regulations

${ }^{3}$ limits for concentrations of heavy metals in consumable parts of plants, as recommended by WTO

${ }^{4}$ toxicity threshold for plants, after Kastori

The total concentrations of the toxic heavy metals $\mathrm{Cr}, \mathrm{Pb}$ and $\mathrm{Cd}$ in both soil layers was below the limit values prescribed by the respective Rulebooks valid in Bosnia and Herzegovina and Serbia. The same statement is true for the other heavy metals analysed, if the measured values are compared with the limits laid down in the related Serbian Rulebook. When analysed in respect of the legal regulations in Bosnia and Herzegovina, copper and zinc levels in the soil were somewhat above the limit values, which in terms of soil contamination should not be a matter of great concern, primarily due to the role of copper and zinc as essential nutrients for plant development. Elevated contents of zinc and copper in soils are assumed to result from the use of mineral fertilisers and plant protection agents, which is a very common occurrence in intensive agricultural production (Topalović et.al., 2011).

The highest contents of available forms of the heavy metals in the soil samples were found for zinc and, in particular, copper, whose content was up to several times as much as that of the other elements. The high content of available forms of copper in the soil, most notably in the topsoil, can be attributed to the high affinity of free copper ions $\left(\mathrm{Cu}^{2+}\right)$ to build chelate bonds with the soil 
organic component, thus becoming retained in the soil and, hence, available to plants (Fernandez-Calvino et. Al., 2009).

Table 2. data also show that the presence of toxic heavy metals - cadmium and lead - in apple fruits was not detected, whereas that of chromium was far below the prescribed limit value, i.e. it was at a desirable safety level. As regards cadmium, it was not realistic to expect any presence of this element in the plant material, given its absence from the soil. The low level of uptake and accumulation of lead and chromium in apple fruits can be attributed chiefly to the low level of available forms of these elements in the soil, as well as to the slightly acid to neutral soil $\mathrm{pH}$ which is unfavourable in terms of their uptake. Namely, in strongly acidic environments, dissolution processes prevail, thus favouring the release of heavy metal ions from different bonds (Smith, 1994). This is how ions of $\mathrm{Cd}, \mathrm{Pb}, \mathrm{Cr}$ and many other heavy metals are released into the soil solution to become readily available to plants. In neutral and, in particular, alkaline environments, heavy metal ions are immobilised, as they bind with hydroxyl ions and carbonates to form undissolvable hydroxides and salts, thereby becoming unavailable to plants (Tack, 2010). This statement is confirmed by a number of other studies on the effect of soil chemical characteristics on the uptake of heavy metals (Blake et. al., 2002; Jovanović et. al., 2006; Fijalkowski et. al. 2012).

An additional reason for the low level of accumulation of lead and chromium in apple leaves and fruits is their poor mobility inside the plant, due to which they are mainly accumulated in the underground parts of the plant after absorption (Vukadinović et. al., 1997). The poor mobility of lead and chromium in the plant was also reported in many other studies (Nemeth et. al., 1993; Nemeček et. al., 2002).

Among the heavy metals tested in the present study, the highest degree of accumulation in both leaves and fruits was observed for zinc, i.e. being manifold higher than that of the other heavy metals analysed. This result is somewhat expected, considering the relatively high content of total and available forms of zinc in the soil. However, as opposed to zinc, the copper content of apple leaves and fruits was quite lower, regardless of the highest level of available forms of copper in the soil. The low copper content in apple fruits compared to zinc was most likely due to poor mobility of copper in the plant as well as to the high concentration of zinc in the soil that is known to have an antagonistic effect on copper uptake (Chaudhry et. al. 1973).

In general, the present results and their comparison with the findings reported in other related studies suggest that neutral soils, as a rule, should not pose any risk to plant cultivation in cases involving potential uptake of heavy metals, except under a high degree of heavy metal contamination of these soils. 


\section{Conclusion}

The dynamics of all heavy metals in the soil-leaf-fruit system, with the exception of zinc, followed the same pattern, being characterised by a relatively high content of total forms of heavy metals in the soil and a very low degree of their accumulation in apple leaves and fruits.

The key reasons for the poor uptake of heavy metals by the root system are the relatively low levels of available forms of heavy metals in the soil and acid to neutral soil $\mathrm{pH}$ which is unfavourable with regard to the uptake of most heavy metals.

Given the above, the study soil can be considered to be of high quality and suitable for safe apple fruit production, if agricultural practices such as fertilisation and plant protection comply with the principles of integral production. In practical terms, this means that any input of potential heavy metal contamination through mineral fertilisers and plant protection agents must be counterbalanced by their removal from the soil through natural means or agricultural activity.

\section{References}

A 1 i, N. A., A t e r, M., S u n a h a r a, G. I., R o b I d o u x, P. Y. (2004). Phytotoxicity and bioaccumulation of cooper and chromium using barley in spiked artificial and natural forest soils. Ecotoxicology and environmental Safety 57: 363-374.

A 11 o w a y, B. J. (1995). Heavy Metals in Soils, 2nd edition . Blackie Academic and Professional, Glasgow, pp. 14-20.

B 1 a k e, L., G o u $1 \mathrm{~d}$ i n g, K. W. T. (2002). Effects of atmospheric deposition, soil pH and acidification on heavy metal contents in soils and vegetation of semi-natural ecosystems at Rothamsted Experimental Station, UK, Plant and Soil 240(2): 235251.

Ch a u dhry, F. M., Shar i f, M., L a t i f, A., Q u r e s h i, R. H. (1973). Zinc-copper antagonism in the nutrition of rice (Oryza sativa L.). Plant and Soil 38(3): 573-580.

E g n e $\mathrm{r}$ H., R i e h m H., D o $\mathrm{m}$ i n g o W. R. (1960). Untersuchungen uber die chemische Bodenanalyseals Grundlage fur die Beurteilung de Nahrstoffzustandes der Boden. II. K. LantbrHogsk. Ann. 26: 199-215.

FAO/WHO Expert Committee on Food Additives (1999). Summary and conclusions. Proceedings of the 53rd Meeting Joint FAO/WHO Expert Committee on Food Additives, Rome, Italy.

Fernande z-Calvino, D., P e rez-Novo, C., Novoa-Munoz, J. C., A $\mathrm{r}$ i a s - E s t e v e z, M. (2009). Copper fractionation and release from soils devoted to different crops, Journal of Hazardous Materials, 167(1-3): 797-802. 
F i j a 1 k o w ski, K., K a c przak, M., Grobe lak, A., P 1 a c e k, A. (2012). The influence of selected soil parameters on the mobility of heavy metals in soils. Inżynieria i Ochrona Środowiska 15(1): 81-92.

$\mathrm{H}$ e, Z. L., Y a n g, X. E., S $\mathrm{t}$ o $\mathrm{f} f \mathrm{e} 11 \mathrm{a}$ b, P. J. (2005). Trace elements in agroecosystems and impacts on the environment. Journal of Trace Elements in Medicine and Biology 19:125-140.

I n t a w o n g s e, M., D e a n, J. R. (2006). Uptake of heavy metals by vegetable plants grown on contaminated soil and their bioavailability in the human gastrointestinal tract. Food Additivies and Contaminants 23(1): 36-48.

ISO - International Standard Organisation (1994). Soil quality - Determination of pH. ISO 10390.

ISO - International Standard Organisation (1995). Soil quality - Extraction of trace elements soluble in aqua regia. ISO 11466.

ISO - International Standard Organisation (1998). Soil quality - Determination of organic carbon by sulfochromic oxidation. ISO 14235 .

ISO - International Standard Organisation (1998). Soil quality - Determination of cadmium, chromium, cobalt, copper, lead, manganese, nickel and zinc - Flame and electrothermal atomic absorption spectrometric methods. ISO 11047.

$\mathrm{J}$ a š i ć, M. (2013). Rezidue i kontaminanti u hrani. Interna skripta. Tehnološki fakultet Univerziteta u Tuzli, str. 56-62.

Jova nović, Z., D j a lović, I., Ko m 1 j e nović, I., Kovač evi ć, V., Cv i j o v i ć, M. (2006). Influences of liming on vertisol properties and yields of the field crops. Cereal Research Communications 34(1): 517-520.

K a s t or i, R., S e ku 1 i ć, P., P e trovi ć, N., A r s e n i j e vić - M a k s i movi ć, I. (2003). Osvrt na granične vrednosti sadržaja teških metala u zemljištu u nas i u svetu. Zbornik radova Instituta za ratarstvo i povrtarstvo 38: 49-58

L i s ja k, M., Š po lj a revi ć, M., A g i ć, D., A nd r ić, D. (2009). Praktikum iz Fiziologije biljaka. Poljoprivredni fakultet u Osijeku.

$\mathrm{N}$ e m e č e k, J., P o d l e š a k ov a, E., V a c h a, R. (2002). Transfer of trace elements with low soil mobility into plants. Rostlinna vyroba 48(2) 45-50.

N e m e th, T., M o $1 \mathrm{n}$ ar, E., C s 111 ag, J., B u j t a s, K., L u k a c s, A., Parta y, G., F e h e r, J., v a n G e n u c h t e n M. T. (1993). Mobility of some heavy metals in soil-plant systems studied on soil monoliths. Water Science \& Technology 28(3-5): 389-398

P a n, J., P 1 a nt, J. A., V o u 1 v o u 1 is, N., O a t e s, C. J., I h 1 e n fe 1 d, C. (2010). Cadmium levels in Europe: implications for human health. Environmental Geochemistry and Health 32: 1-12.

R. K a s t or i, P e trovi ć, N., A r s e n i j e vi ć - M a k s i movi ć, I. (1997). Teški metali i biljke. u: R. Kastori (red.), Teški metali u životnoj sredini, Naučni Institut za ratarstvo i povrtarstvo, Novi Sad, str. 195-247.

$\mathrm{S} \mathrm{m} \mathrm{i} \mathrm{t} \mathrm{h,} \mathrm{S.} \mathrm{R.} \mathrm{(1994).} \mathrm{Effect} \mathrm{of} \mathrm{soil} \mathrm{pH}$ on availability to crops of metals in sewage sludge-treated soils. I. Nickel, copper and zinc uptake and toxicity to ryegrass. Environmental pollution 85(3): 321-327.

T a c k, F. M. G. (2010): Trace Elements: General Soil Chelistry Principles and Processes. In: Hooda, P. S. (ur.): Trace Elements in Soils. A John Wiley and Sons, Ltd., Publication. United Kingdom, pp. 9-38. 
T o p a lović, A., P fe ndt, P., P e t r o vić, N., K n e ž e vić, M. (2011). Status of $\mathrm{Pb}$ and $\mathrm{Cu}$ in the calcareous soils of Ćemovsko field. Zemljište i biljka 60(2): 7584.

Trierweler, F.J., Lindsay, W.L. (1969). EDTA-ammonium carbonate test for Zn. Soil Science Society of America Proceedings 33: 49-54

V u k a d i n o v i ć, V., L o n č a r i ć, Z. (1997). Ishrana bilja. Poljoprivredni fakultet u Osijeku, Osijek. 


\title{
DINAMIKA TEŠKIH METALA U SISTEMU ZEMLJIŠTE-LIST-PLOD U INTENZIVNOM UZGOJU JABUKE (Malus domestica Borkh.)
}

\author{
Senad Murtić \\ Poljoprivredno-prehrambeni fakultet, Sarajevo, Bosna i Hercegovina
}

Duško Brković, Milena Djurić, Ivan Vujinović

Agronomski fakultet Čačak, Srbija

\begin{abstract}
Rezime
Jedan od velikih problema $\mathrm{u}$ poljoprivrednoj proizvodnji predstavlja onečišćenost zemljišta teškim metalima jer je mogućnost produkcije na takvim zemljištima znatno organičena, a proizvodi koji se na njima dobivaju su vrlo upitni sa aspekta zdravlja potrošača. Cilj ovog istraživanja je bio ispitati dinamiku teških metala u sistemu zemljište - list - plod u intenzivnom uzgoju jabuke sorte Idared smještenom na područjuju opštine Goražde. Sadržaj teških metala $u$ ispitivanim uzorcima zemljišta i biljnom materijalu određen je metodom atomske apsorpcione spektrofotometrije na aparatu Shimadzu 7000 AA, a prema uputstvima sadržanim u metodi ISO11047. Dinamika svih ispitivanih teških metala u sistemu zemljište - list - plod jabuke, uz izuzetak cinka, je bila obilježena sa relativno visokim sadržajem ukupnih oblika teških metala u zemljištu, te sa vrlo niskim stepenom njihove akumulacije u listovima, a posebno u plodovima jabuke.U niti jednom ispitivanom uzorku ploda jabuke nije utvrđena toksična vrijednost za sadržaj pojedinog teškog metala, što promatrano sa aspekta onečišćenja zemljišta ukazuje na pogodnost korištenja ispitivanog lokaliteta za proizvodnju zdravstveno ispravnih plodova jabuke.
\end{abstract}

Ključne reči: zemljište, list, plod, teški metali. 